\title{
The Risk Factors of Bacterial Meningitis in Late-Onset Neonatal Sepsis
}

Ni Made Reditya Noviyani, I. Made Kardana*, Dewi Sutriani Mahalini, Ida Bagus Gede Suparyatha, Ketut Ariawati, Gusti Ayu Putu Nilawati, Made Sukmawati

Department of Child Health, Faculty of Medicine, Udayana University, Sanglah Hospital, Denpasar, Bali, Indonesia

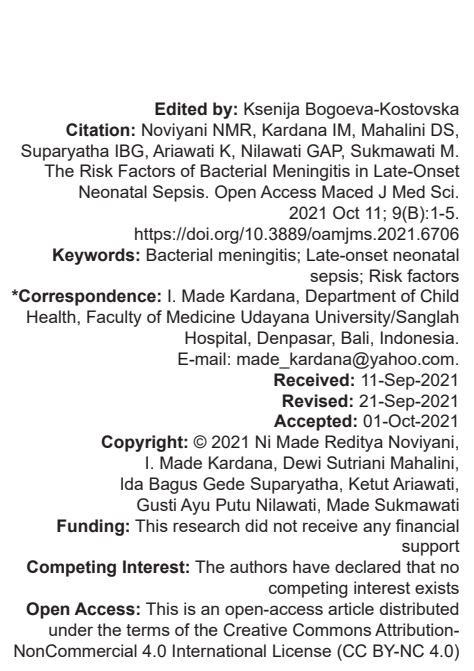

\begin{abstract}
BACKGROUND: Neonatal bacterial meningitis has a significant contribution on neonatal morbidity and mortality. It is the most common complication of late-onset neonatal sepsis. An understanding of the risk factors for bacterial meningitis in late-onset neonatal sepsis is required to provide comprehensive management.

AIM: To identify the risk factors of bacterial meningitis in late-onset neonatal sepsis.

METHODS: This is an analytical study with a case-control design, conducted in May 2019-February 2021, involving neonates aged 4-28 days who suffered from late-onset neonatal sepsis in Level II and III Neonatal Care Unit, Sanglah General Hospital Denpasar. Statistical analysis was performed using Chi-square and logistic regression.

RESULTS: A total of 54 patients were analyzed in this study. The mean age of subjects with neonatal bacteria meningitis was 13 days and the majority of them were male $(51.9 \%)$. The risk factor of bacterial meningitis in lateonset neonatal sepsis was gestational age $<37$ weeks with odds ratio 4.22 (95\% confidence interval $1.28-13.86$, $p=0.01$ ). There was no significant association of birth weight $<2500 \mathrm{~g}$, neonatal asphyxia, and invasive procedure on neonatal bacterial meningitis.
\end{abstract}

CONCLUSION: Gestational age $<37$ weeks is a risk factor for bacterial meningitis in late-onset neonatal sepsis.

\section{Background}

Neonatal bacterial meningitis is an inflammation of the meninges which happens during the first 28 days of life, with evidence of the presence of bacteria in the cerebrospinal fluid (CSF). The incidence of neonatal meningitis ranges from 0.25 to $1 / 1000$ live births and occurs in $25 \%$ of neonates with bacteremia. Approximately $10 \%$ of affected infants died and $20-50 \%$ of survivors develop seizures, hearing and visual impairments, cognitive problems, and motoric abnormalities [1], [2], [3]. The prenatal risk factors of neonatal bacterial meningitis were premature rupture of membrane, maternal vaginitis, asymptomatic bacteriuria, preterm infants, low birthweight infants, and asphyxia [4].

Neonatal bacterial meningitis is the most common complication of neonatal sepsis. In developing countries, meningitis was found in 2.4-12.7 of 7.138 cases of neonatal sepsis per 1000 births [5], [6]. The prevalence of neonatal meningitis in clinical sepsis at the Neonatal Intensive Care Unit, Sanglah General Hospital Denpasar was $68.8 \%$ [7]. A study by Arora et al. also reported 55 cases of meningitis (61.11\%) in 90 patients with suspected late-onset neonatal sepsis [8].

Diagnosis of neonatal bacterial meningitis is based on clinical manifestations and examination of CSF. The culture of CSF is the gold standard for diagnosing neonatal bacterial meningitis [4], [6]. Negative CSF culture in most cases of meningitis can be caused by previous use of antibiotics or incompatibility of culture media. Polymerase chain reaction (PCR) examination can be used to detect pathogens in the CSF of patients with a history of previous use of antibiotics. The PCR has a sensitivity of $86 \%$, specificity of $97 \%$, a positive predictive value of $80 \%$, and a negative predictive value of $98 \%$ compared to culture [9].

The initial manifestations of neonatal bacterial meningitis and neonatal sepsis are nonspecific and difficult to distinguish [4]. It can cause a delay in diagnosis and in turn, affect the prognosis and survival of patients [10]. The mortality rate in neonates with meningitis in suspected late-onset sepsis was 45.5\% [8]. Based on this background, we need to identify the risk factors of bacterial meningitis in late-onset neonatal sepsis at Sanglah General Hospital, Denpasar. 


\section{Methods}

This is an analytical study with a case-control design (without matching), conducted in May 2019February 2021, involving neonates aged 4-28 days who suffered from late-onset neonatal sepsis at Level II and III Neonatal Care Unit, Sanglah General Hospital Denpasar. A total of 54 patients participated in this study and these patients were obtained using consecutive sampling method. The exclusion criteria include major congenital anomaly, congenital infection, and intracranial hemorrhage. Data were collected from medical records and laboratory examination results. The case group was neonates with late-onset sepsis and bacterial meningitis, while the control group was neonates with late-onset sepsis and no bacterial meningitis. The data were then analyzed statistically using the Chi-square test and logistic regression.

In this study, neonatal bacterial meningitis is defined as neonates with late-onset sepsis who fulfilled the clinical and CSF analysis criteria, including pleocytosis $\left(>20\right.$ leukocytes $\left./ \mathrm{mm}^{3}\right)$, dominant polymorphonuclear cells, and/or decreased glucose levels $(<20-30 \mathrm{mg} / \mathrm{dl})$ or CSF glucose $<2 / 3$ serum glucose, and/or increased CSF protein levels (>150 mg/dl), and a positive universal primer (16S ribosomal Ribonucleic acid) PCR test as the presence of bacteria, with or without positive CSF culture results [6], [9]. Late-onset neonatal sepsis is defined as a systemic illness accompanied by bacteremia occurring in neonates aged $>3$ days and characterized by clinical manifestations and at least 2 positive laboratory examinations including leukocytes count $<5000$ or $>35,000 / \mu \mathrm{L}$, neutropenia $<1500 / \mu \mathrm{L}$ or neutrophilia, platelets $<150,000 / \mu \mathrm{L}$, procalcitonin $\geq 0.05 \mathrm{ng} / \mathrm{mL}$, or (immature to total neutrophil) IT ratio $>0.2$, with or without positive blood culture results [6].

Gestational age is defined as the period from conception to the time of birth, calculated from the $1^{\text {st }}$ day of the last menstrual period or assessed for neonates using the New Ballard Score or Finstrom Score. Preterm infant is defined if the baby was born $<37$ weeks of gestation. Birth weight is the weight of the baby measured within $1 \mathrm{~h}$ after birth. Low birth weight is defined as the birth weight of $<2500 \mathrm{~g}$ regardless of gestation [11]. Neonatal asphyxia is a newborn condition based on the results of the appearance, pulse, grimace, activity, and respiration (APGAR) score examination at the $1^{\text {st }}$ min after birth. Asphyxia is defined if the APGAR score is $<7$ [12]. Invasive procedure is defined as procedure associated with a technique of inserting a device into the body, including insertion of an umbilical catheter and/or a central venous catheter (peripherally inserted central catheter and/or central venous line) and/or endotracheal intubation [13]

This study has obtained ethical clearance from the Research Ethics Committee of Faculty of
Medicine, Universitas Udayana/Sanglah Hospital (314/ UN.14.2.2.VII.14/LP/2019) and the Indonesian Ministry of Health, Directorate General of Health Services (LB.02.01/XIV.2.2.1/13814/2019).

\section{Result}

A total of 58 patients with late-onset neonatal sepsis were found during this research period, of which three patients with multiple congenital anomalies and 1 patient with congenital rubella infection were excluded as described in Figure 1. A total of 54 patients were analyzed in this study. The mean age of subjects with neonatal bacterial meningitis was 13 days and the majority of them were male $(51.9 \%)$. The median gestational age was 33 weeks (minimum-maximum 25-40 weeks) with a mean birth weight of $2035 \pm 822 \mathrm{~g}$. Positive blood culture results were obtained in $18.5 \%$ of subjects with bacterial meningitis. Eschericia coli, Klebsiella pneumonia, Staphylococcus haemolyticus, Klebsiella oxytoca, and Serratia marcescens were found in the blood culture results. Positive CSF culture results were obtained in $3.7 \%$ of patients with bacterial meningitis and Pseudomonas aeruginosa was found in this result. The presence of neonatal bacterial meningitis was confirmed by a positive result of PCR examination of CSF with universal primer. The characteristics of subjects are described in Table 1.

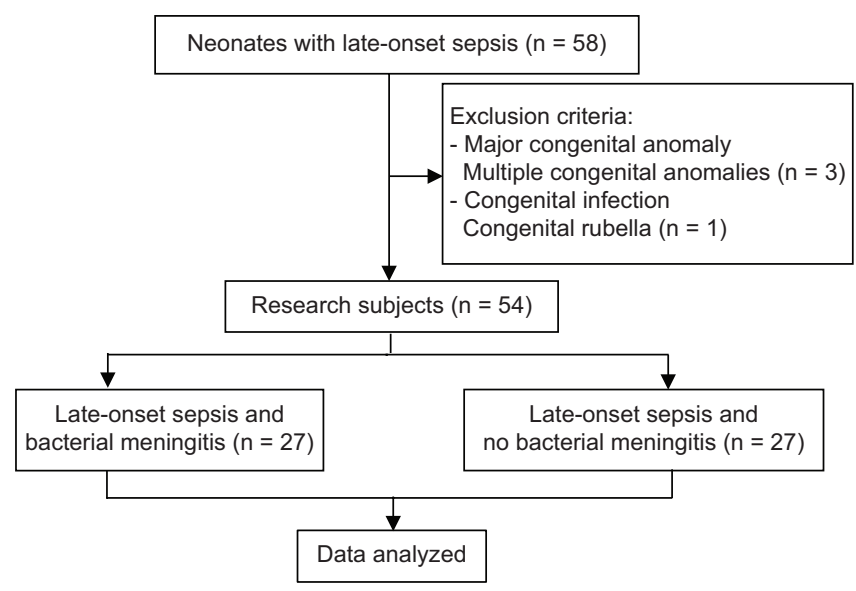

Figure 1: Study flow chart

The risk factor of bacterial meningitis in lateonset neonatal sepsis was gestational age $<37$ weeks with odds ratio (OR) of 4.22 (95\% confidence interval [CI] 1.28-13.86, $p=0.01)$. There was no significant association of birth weight $<2500 \mathrm{~g}$, neonatal asphyxia, and invasive procedures on neonatal bacterial meningitis in this study. The results of the bivariate and multivariate analysis in this study are shown in Tables 2 and 3. 
Table 1: Characteristics of subjects

\begin{tabular}{|c|c|c|}
\hline Characteristics & $\begin{array}{l}\text { Bacterial meningitis } \\
(\mathrm{n}=27)\end{array}$ & $\begin{array}{l}\text { No bacterial } \\
\text { meningitis }(n=27)\end{array}$ \\
\hline $\begin{array}{l}\text { Age, mean } \pm \text { SD, days } \\
\text { Gender, } n(\%)\end{array}$ & $13 \pm 6.5$ & $15 \pm 7.5$ \\
\hline Male & $14(51.9)$ & $16(59.3)$ \\
\hline Female & $13(48.1)$ & $11(40.7)$ \\
\hline Gestational age, n (\%) & & \\
\hline$<37$ weeks & $18(66.7)$ & $8(29.6)$ \\
\hline$\geq 37$ weeks & $9(33.3)$ & $19(70.4)$ \\
\hline Birth weight, n (\%) & & \\
\hline$<2500 \mathrm{~g}$ & $17(63.0)$ & $12(44.4)$ \\
\hline$\geq 2500 \mathrm{~g}$ & $10(37.0)$ & $15(55.6)$ \\
\hline Neonatal asphyxia, n (\%) & & \\
\hline Asphyxia & $11(40.7)$ & $6(22.2)$ \\
\hline No asphyxia & $16(59.3)$ & $21(77.8)$ \\
\hline Invasive procedure, n (\%) & & \\
\hline Invasive procedure & $17(63.0)$ & $16(59.3)$ \\
\hline $\begin{array}{l}\text { No invasive procedure } \\
\text { Blood Panel }\end{array}$ & $10(37.0)$ & $11(40.7)$ \\
\hline $\begin{array}{l}\text { Leukocyte, median (min-max) } \\
\text { Absolute neutrophil, median (min-max) } \\
\text { Platelet, mean } \pm \text { SD } \\
\text { IT ratio, median (min-max) } \\
\text { Procalcitonin, median (min-max) } \\
\text { Blood culture, } \mathrm{n}(\%)\end{array}$ & $\begin{array}{l}15.17(6.16-53.43) \\
8.35(3.40-42.65) \\
242 \pm 188 \\
0.18(0.01-0.87) \\
0.90(0.10-119)\end{array}$ & $\begin{array}{l}11.30(2.15-33.77) \\
5.20(0.65-20.22) \\
335 \pm 172 \\
0.08(0.01-2.20) \\
0.75(0.07-452)\end{array}$ \\
\hline $\begin{array}{l}\text { Growth } \\
\text { No growth } \\
\text { CSF cells, } n(\%)\end{array}$ & $\begin{array}{l}5(18.5) \\
22(81.5)\end{array}$ & $\begin{array}{l}5(18.5) \\
22(81.5)\end{array}$ \\
\hline $\begin{array}{c}\leq 20 \text { cells } / \mathrm{mm}^{3} \\
>20 \text { cells } / \mathrm{mm}^{3} \\
\text { CSF glucose, } \mathrm{n}(\%)\end{array}$ & $\begin{array}{l}4(14.8) \\
23(85.2)\end{array}$ & $\begin{array}{l}27(100) \\
0(0)\end{array}$ \\
\hline $\begin{array}{l}<2 / 3 \text { blood glucose } \\
\geq 2 / 3 \text { blood glucose } \\
\text { CSF protein, } n(\%)\end{array}$ & $\begin{array}{l}27(100) \\
0(0)\end{array}$ & $\begin{array}{l}0(0) \\
27(100)\end{array}$ \\
\hline $\begin{array}{l}\leq 150 \mathrm{mg} / \mathrm{dL} \\
>150 \mathrm{mg} / \mathrm{dL}\end{array}$ & $\begin{array}{l}17(63.0) \\
10(37.0)\end{array}$ & $\begin{array}{l}22(81.5) \\
5(18.5)\end{array}$ \\
\hline CSF culture, n (\%) & & \\
\hline $\begin{array}{l}\text { Growth } \\
\text { No growth }\end{array}$ & $\begin{array}{l}1(3.7) \\
26(96.3)\end{array}$ & $\begin{array}{l}0(0) \\
27(100)\end{array}$ \\
\hline
\end{tabular}

\section{Discussion}

The proportion of neonatal bacterial meningitis was higher in males (51.9\%) with the ratio of males and females of 1.07:1. This finding is similar to the previous study which found a higher incidence of neonatal bacterial meningitis in males [14]. Several studies have shown that there is gender-linked susceptibility to meningitis, in which male is more prone to develop neonatal meningitis. One of the possible explanations is that the factors regulating the synthesis of globulins are situated on the $X$ chromosome. Since male only has one $X$ chromosome, they are less immunologically protected than the females [4], [15], [16].

Table 2: Bivariate analysis of risk factors for bacterial meningitis in late-onset neonatal sepsis

\begin{tabular}{|c|c|c|c|c|}
\hline Variable & $\begin{array}{l}\text { Bacterial } \\
\text { meningitis } \\
n=27\end{array}$ & $\begin{array}{l}\text { No } \\
\text { bacterial } \\
\text { meningitis } \\
n=27\end{array}$ & OR $(95 \% \mathrm{Cl})$ & $p$ value \\
\hline $\begin{array}{l}\text { Gestational age } \\
<37 \text { weeks, } \mathrm{n}(\%)\end{array}$ & $18(66,7)$ & $8(29.6)$ & $4.75(1.50-15.0)$ & 0.01 \\
\hline $\begin{array}{l}\text { Birth weight } \\
<2500 \mathrm{~g}, \mathrm{n}(\%)\end{array}$ & $17(63)$ & $12(44.4)$ & $2.12(0.71-6.31)$ & 0.27 \\
\hline $\begin{array}{l}\text { Neonatal } \\
\text { asphyxia, n (\%) }\end{array}$ & $11(40.7)$ & $6(22.2)$ & $2.40(0.73-7.89)$ & 0.24 \\
\hline $\begin{array}{l}\text { Invasive } \\
\text { procedure, n (\%) }\end{array}$ & $17(63)$ & $16(59.3)$ & $1.16(0.39-3.49)$ & 1.0 \\
\hline
\end{tabular}

Lumbar puncture is the main procedure for the diagnosis of neonatal bacterial meningitis. The increase in cells $>20$ cells $/ \mathrm{mm}^{3}$ on CSF examination has a sensitivity of $92.31 \%$ and a specificity of $81.48 \%$ for the diagnosis of meningitis [17]. However, neonatal meningitis can occur without an increase in CSF cells due to a wide variation in the normal range of cells based on age and birth weight [18]. In this study, $14.8 \%$ of patients with neonatal bacterial meningitis had CSF cells $\leq 20$ cells $/ \mathrm{mm}^{3}$. This finding is similar to the previous study which found three cases of neonatal meningitis with CSF cells of $<20$ cells $/ \mathrm{mm}^{3}$ [7].

Table 3: Multivariate analysis of risk factors for bacterial meningitis in late-onset neonatal sepsis

\begin{tabular}{llll}
\hline Variable & OR & $95 \% \mathrm{Cl}$ & p value \\
\hline Gestational age $<37$ weeks & 4.22 & $1.28-13.86$ & 0.01 \\
Neonatal asphyxia & 1.60 & $0.44-5.84$ & 0.47 \\
\hline
\end{tabular}

CSF glucose and protein levels have a lower sensitivity in diagnosing neonatal meningitis. A history of antibiotic administration before CSF examination can affect the results of the CSF glucose and protein levels. Prior administration of antibiotics can lead to high levels of CSF glucose and low levels of CSF protein [19]. In this study, CSF glucose levels were in accordance with the criteria for meningitis, and CSF protein levels of $\leq 150 \mathrm{mg} / \mathrm{dl}$ were found in $63 \%$ of subjects with neonatal bacterial meningitis.

In this study, positive blood culture results were obtained in $18.5 \%$ of patients with neonatal bacterial meningitis. Positive CSF culture results could be found in $30 \%$ of neonates with positive blood culture results [20]. However, in this study, positive CSF culture results were only detected in $3.7 \%$ of patients with neonatal bacterial meningitis. In a study of Sharifi-Mood et al., 46 (86.79\%) of 53 patients with meningitis had negative CSF culture results. The negative results of CSF culture in most cases of meningitis can be caused by previous use of antibiotics or inappropriate culture media [21].

S. haemolyticus, E. coli, K. pneumonia, $K$. oxytoca, and $S$. marcescens were found in the blood cultures of subjects with neonatal bacterial meningitis. These bacteria were not found in the CSF cultures of patients. Group B streptococci (especially type III), E. coli, and Listeria monocytogenes are the main causes of neonatal meningitis [18]. In this study, $P$. aeruginosa was found in CSF culture results. $P$. aeruginosa is a Gram-negative rod bacteria and a rare cause of neonatal meningitis. The infection of $P$. aeruginosa could be of nosocomial origin [3].

In this study, the presence of bacteria in the CSF of meningitis subjects with no growth culture was identified by PCR examination with universal primer. Positive PCR results were obtained in all subjects whose CSF analysis results fulfilled the diagnosis criteria for neonatal bacterial meningitis. This PCR examination can detect pathogens in CSF higher than CSF culture ( $72 \%$ vs. $48 \%)$. In patients with a history of previous use of antibiotics, the ability of PCR to detect pathogens in CSF is also higher than in culture $(58 \%$ vs. $29 \%$ ) [22], [23].

The risk factor of bacterial meningitis in late-onset neonatal sepsis was gestational age $<37$ weeks with OR $4.22(95 \% \mathrm{Cl} 1.28-13.86)$. 
A similar finding was found in a study of risk factors for neonatal meningitis in clinical sepsis [7]. The risks of neonatal bacterial meningitis increase with decreasing gestational age. Preterm infants with sepsis have 3 times higher incidence of central nervous system infections compared to term infants. Immaturity of the neonatal immune system, impaired phagocytic ability of neutrophils and monocytes, and decreased antibodies from the mother contribute to an increased risk of infection in preterm infants. These factors enable the pathogens to be able to reach the meninges through the bloodstream even though the pathogens have a low degree of virulence. The alternative pathway complement system in preterm infants is also ineffective, resulting in impaired defense mechanism against encapsulated bacteria in this population [6], [20], [24]. The development of the blood-brain barrier occurs at the end of gestation and continues into the period after birth. The increased permeability of the developing blood-brain barrier may also increase the susceptibility to infection [25].

Birth weight of $<2500 \mathrm{~g}$, neonatal asphyxia, and invasive procedures were not independent factors of bacterial meningitis in late-onset neonatal sepsis. This is possibly because there is no significant difference in the number of neonates without bacterial meningitis, both in the birth weight group $<2500 \mathrm{~g}$ and $\geq 2500 \mathrm{~g}(44.4 \%$ vs. $55.6 \%)$. Furthermore, the percentage of non-asphyxia neonates with bacterial meningitis was higher (59.3\%) compared to neonates with asphyxia and there was no significant difference in the number of neonates who received invasive procedures, both in bacterial meningitis and no bacterial meningitis groups $(63 \%$ vs. $59.3 \%)$. The limitations of this study include the case-control study design without matching and the diagnosis using PCR examination which only determined the presence of bacteria in the CSF. Consequently, further studies with prospective cohort design are needed to identify the other risk factors of bacterial meningitis and also examination of bacterial species through the PCR sequence of CSF patients with neonatal bacterial meningitis.

\section{Conclusion}

Gestational age of $<37$ weeks is a risk factor for bacterial meningitis in late-onset neonatal sepsis. The understanding of this risk factor is important to determine the policy for the comprehensive management of neonates with late-onset sepsis, especially on the prevention of bacterial meningitis.

\section{References}

1. Hristeva L, Booy R, Bowler I, Wilkinson AR. Prospective surveillance of neonatal meningitis. Arch Dis Child. 1993;69(1 Spec No):14-8. https://doi.org/10.1136/adc.69.1_spec_no.14 PMid:8346945

2. Klein JO. Bacterial meningitis and sepsis. In: Remington JS, Klein JO, editor. Infectious Diseases of the Fetus and Newborn Infant. $4^{\text {th }}$ ed. Philadelphia, PA: WB Saunders; 2006. p. 943-98.

3. Gordon SM, Srinivasan L, Harris MC. Neonatal meningitis: Overcoming challenges in diagnosis, prognosis, and treatment with omics. Front Pediatr 2017;5:139. https://doi.org/10.3389/ fped.2017.00139

PMid:28670576

4. Khalessi N, Afsharkhas L. Neonatal meningitis: Risk factors causes and neurologic complications. Iran J Child Neurol. 2014;8(4):46-50

PMid:25657770

5. Vergnano S, Sharland M, Kazembe P, Mwansambo C, Heath PT Neonatal sepsis: An international perspective. Arch Disc Child Fetal Neonatal Ed. 2005;90(3):F220-4. https://doi.org/10.1136/ adc. 2002.022863

PMid:15846011

6. Gomella TL. Meningitis. In: Gomella TL, Cunningham MD, Eyal FG, editors. Neonatology, Management, Procedures, on-Call Problems, Disease and Drugs. $7^{\text {th }}$ ed. United States: The McGraw-Hill Education LLC; 2013. p. 1009-12.

7. Rachman A, Artana WD, Sukmawati M. Prevalens meningitis neonatal dan faktor-faktor yang memengaruhi pada bayi klinis sepsis di ruang NICU RSUP Sanglah Denpasar. Medicina. 2017;48(2):113-7. https://doi.org/10.15562/medicina.v48i2.38

8. Arora V, Sharma LM, Jangid D, Choudhary V, Bairwa RP, Singla S. Meningitis in late onset sepsis. Int J Contemp Pediatr. 2017;4(3):1056-60. https://doi.org/10.18203/2349-3291. ijcp20171727

9. Schuurman $T$, de Boer RF, Kooistra-Smid AM, van Zwet AA. Prospective study of use of PCR amplification and sequencing of $16 S$ ribosomal DNA from cerebrospinal fluid for diagnosis of bacterial meningitis in a clinical setting. J Clin Microbiol. 2004;42(2):734-40. https://doi.org/10.1128/ JCM.42.2.734-740.2004

PMid: 14766845

10. Aminullah A. Sepsis pada bayi baru lahir. In: Kosim MS, Yunanto A, Dewi R, Sarosa GI, Usman A, editors. Buku Ajar Neonatologi. $1^{\text {st }}$ ed. Jakarta: Badan Penerbit IDAI; 2014. p. $170-87$.

11. Damanik SM. Klasifikasi bayi menurut berat lahir dan masa gestasi. In: Kosim MS, Yunanto A, Dewi R, Sarosa GI, Usman A editor. Buku Ajar Neonatologi. $1^{\text {st }}$ ed. Jakarta: Badan Penerbit IDAI; 2014. p. 12-3.

12. Dharmasetiawani N. Asfiksia dan resusitasi bayi baru lahir. In Kosim MS, Yunanto A, Dewi R, Sarosa GI, Usman A, editor Buku Ajar Neonatologi. $1^{\text {st }}$ ed. Jakarta: Badan Penerbit IDAI; 2014. p. $103-4$

13. Romanelli RM, Anchieta LM, Mourao MV, Campos FA Loyola FC, de Jesus LA. Notification of healthcare associated infections based on international criteria performed in a reference neonatal progressive care unity in Belo Horizonte, MG. Rev Bras Epidemiol. 2013;16(1):77-86.

PMid:23681325

14. Ismail AM, Quadri S. Incidence, Clinical profile and etiology of meningitis in term neonates with clinical sepsis. Galore Int $J$ Health Sci Res. 2019;4(3):51-9.

15. Russell GA, Smyth A, Cooke RW. Receiver operating 
characteristic curves for comparison of serial neutrophil band forms and C-reactive protein in neonates at risk of infection. Arch Dis Child. 1992;67(7):808-12. https://doi.org/10.1136/ adc.67.7_spec_no.808

PMid:1519980

16. Klinger G, Chin CN, Beyene J. Predicting the outcome of neonatal bacterial meningitis. Pediatrics. 2000;106(3):477-82. https://doi.org/10.1542/peds.106.3.477

PMid:10969090

17. Ariputra, Kardana IM, Suwarba IG. Correlation among Blood Cultures, Cerebrospinal Fluid Parameters, and Cerebrospinal Fluid Cultures in Neonatal Meningitis. Child Health Department Medical School Udayana University/Sanglah Hospital Denpasar; 2014. p. 1-12.

18. Furyk JS, Swann O, Molyneux E. Systematic review: Neonatal meningitis in the developing world. Trop Med Int Health. 2011;16:672-9. https://doi. org/10.1111/j.1365-3156.2011.02750.x

PMid:21395927

19. Nigrovic LE, Malley R, Maclas CG, Kanegaye JT, MoroSutherland DM, Schremmer RD. Effect of antibiotic pretreatment on cerebrospinal fluid profiles of children with bacterial meningitis. Pediatrics. 2008;122(4):726-30. https://doi. org/10.1542/peds.2007-3275

PMid:18829794

20. Ku LC, Boggess KA, Cohen-Wolkowiez M. Bacterial meningitis in the infant. Clin Perinatol. 2015;42(1):29-45. https://doi. org/10.1016/j.clp.2014.10.004

PMid:25677995

21. Sharifi-Mood B, Khajeh A, Metanat M, Rasouli A. Epidemiology of meningitis studied at university hospital in Zahedan, SouthEastern Iran. Int J Infect. 2015;2:1-3. https://doi.org/10.17795/ iji-23634

22. Chiba N, Murayama SY, Morozumi M, Nakayama E, Okada T, Iwata S. Rapid detection of eight causative pathogens for the diagnosis of bacterial meningitis by real-time PCR. J Infect Chemother. 2009;15(2):92-8. https://doi.org/10.1007/ s10156-009-0670-3

23. Klindworth A, Pruesse E, Schweer T, Peplies J, Quast C, Horn M, et al. Evaluation of general 16S ribosomal RNA gene PCR primers for classical and next-generation sequencing-base diversity studies. Nucleic Acids Res. 2013;41(1):1-11. https:// doi.org/10.1093/nar/gks808

24. Krebs VL, Costa GA. Clinical outcome of neonatal bacterial meningitis according to birth weight. Arq Neuropsiquiatr. 2007;65(4B):1149-53. https://doi.org/10.1590/ s0004-282x2007000700011

PMid: 18345420

25. Shaha CK, Dey SK, Shabuj KH, Chisti J, Mannan MA, Jashimuddin M. Neonatal sepsis a review. Bangladesh J Child Health. 2012;36(2):82-9. https://doi.org/10.3329/bjch. v36i2.13084 